\title{
Izgladnjivanje kao sudskomedicinski problem
}

\section{Starvation as an issue in legal medicine}

\author{
Ivan Šoša ${ }^{1^{*}}$, Filip Štefanac ${ }^{2}$, Valter Stemberga ${ }^{1}$
}

\author{
${ }^{1}$ Zavod za sudsku medicinu i kriminalistiku, \\ Medicinski fakultet Sveučilišta u Rijeci, \\ Rijeka \\ ${ }^{2}$ Medicinski fakultet Sveučilišta u Rijeci, \\ Rijeka
}

Sažetak. Izgladnjivanje do smrti samo je iznimno uzrok smrti u razvijenim zemljama. Međutim, ova pojava može imati daleko veći značaj ako je sudskomedicinski gledano smrt posljedica namjernog uskraćivanja hrane. U takvim slučajevima zadatak specijalista sudske medicine ili patologa je razjasniti uzrok smrti i dati stručno mišljenje o stupnju i trajanju gladi. Za procjenu proteinsko-energijske pothranjenosti razvijeno je nekoliko klasifikacijskih sustava koji se također opisuju u članku. Mnogo je faktora vezanih uz dob koji mogu dovesti do gubitka apetita i smanjenja težine, te se u preglednom članku oni i razmatraju. Sudskomedicinski su posebno interesantni slučajevi izgladnjivanja u kojima su, u sklopu pojave zlostavljanja i zanemarivanja, pogođena djeca,. Upravo takve primjere iz literature i navodimo u radu, uz osvrt na osobe starije životne dobi. Ove su osobe, zbog nerazmjera u odnosu snaga, posebno ugrožena skupina, kod koje je također najčešći tip pothranjenosti proteinsko-energijska pothranjenost.

Ključne riječi: djeca; izgladnjivanje; zanemarivanje

Abstract. Starvation with a fatal outcome is just an exceptional cause of death in developed countries. However, this phenomenon may have far greater significance if a criminal case related-death is the consequence of deliberate denial of food. In such cases, the task of a specialist in the field of legal medicine or pathology is to clarify the cause of death and give a professional opinion on the degree and duration of violent starvation. For the evaluation of protein-energy malnutrition, several classification systems have been developed, which are also described in the article. There are many age-related factors that can lead to loss of appetite and weight loss, and they are being considered in this review article. Suddenly, specially interesting cases of starvation affect children, as a result of abuse and neglect. It is precisely these examples from the literature and we are cited in this paper, concerning older people. These people, due to the unbalanced relationship of strength, are particularly vulnerable to the group, which is also the most common type of malnutrition protein-energy malnutrition.

Key words: children; neglection; starvation

\author{
*Dopisni autor: \\ Doc. dr. sc. Ivan Šoša, dr. med. \\ Zavod za sudsku medicinu i kriminalistiku \\ Medicinskog fakulteta u Rijeci \\ Vukovarska 11, 51000 Rijeka \\ e-mail: ivan.sosa@medri.uniri.hr
}




\section{UVOD}

Gladovanje je jedna od najvažnijih široko rasprostranjenih negativnih pojava današnjice. Ovdje raspravljamo $o$ individualnom zanemarivanju $s$ kojim je gladovanje često povezano, bilo kao potencijalno kazneno djelo, bilo kao manifestacija samozanemarivanja. Kao i kod mnogih drugih fenomena u sudskoj medicini, razdoblja na početku i na kraju života su najkritičnija upravo zbog nerazmjera snaga žrtve i počinitelja; nejakosti, podčinjenosti i ovisnosti žrtve o počinitelju. Dojenčad i djeca, ali i osobe starije životne dobi koje, primjerice, boluju od demencije, nerijetko nemaju bližnjih koji bi brinuli o njima ili su bez financijskih sredstava, te su prepušteni svojim roditelja ili skrbnicima. Mnoge zemlje zakonima štite djecu, budući da ona, kako bi zadovoljila životne potrebe, potpuno ovise o odraslim osobama ${ }^{1}$. Hrvatskom zakonodavstvu slična regulativa obvezuje $\mathrm{i}$ djecu da skrbe o nemoćnim roditeljima.

Gladovanje rijetko uzrokuje smrt u razvijenim zemljama, ali može postati iznimno sudskomedicinski bitno u slučaju da dođe do smrti uslijed namjerne uskrate hrane, što se i viđa kao posljedica zlostavljanja i zanemarivanja djeteta, izgladnjivanja nasmrt ili kod mentalno bolesnih osoba. U takvim slučajevima zadatak specijalista sudske medicine, patologa i istražitelja nije samo razjasniti uzrok smrti, već i dati stručno medicinsko mišljenje o stupnju i trajanju gladi. Razvijeno je nekoliko klasifikacijskih sustava za procjenu pothranjenosti u zemljama trećeg svijeta (npr. Waterlowljeva klasifikacija, Gomezova klasifikacija)2. Neke jednostavnije klasifikacije, poput Gomezove, kao standard koriste tjelesnu težinu. Međutim, tjelesna težina treba biti povezana $s$ očekivanom težinom za stvarnu visinu. Koristeći takve klasifikacijske sustave u pravnim slučajevima može se odrediti gubitak težine u odnosu na očekivanu tjelesnu težinu, što je od velikog značaja za procjenu žrtvinog nutritivnog statusa. Upravo s tim ciljem i razvijaju se klasifikacijski sustavi kojima se procjenjuje „zaostajanje“ (negativno odstupanje, postotak od normalnog ili očekivanog) primjerice Waterlowljeva klasifikacija. Ona nije važna samo za ocjenjivanje završne faze gladovanja čiji ishod je smrt, već i za kronologiju prehrambenog statusa, naravno u slučaju da su antropometrijski podaci zabilježeni više puta za vrijeme života.

Dijagnoza smrti koja je posljedica gladi obično je jednostavna, vizualne značajke izgladnjelih dobro su poznate iz pomodarstva koje se ogleda kroz „trend mršavosti“. Ako postoji opsežna okolnosna dokumentacija, čak ni na temelju indicija ne bi trebalo biti teško postaviti dijagnozu. Okolnosti kod kojih smrtni ishod ne bi trebao biti neočekivan su:

- Nemogućnost uzimanja hrane (npr. kod nekih prirodnih bolesti kao što je karcinom jednjaka).

- Dobrovoljno odbijanje hrane (post do smrti, štrajk glađu).

- Mentalna bolest (anoreksija, shizofrenija).

- Slučajno „sahranjivanje“ (nesreće - potresi).

- Namjerno uskraćivanje hrane².

Iznimno je bitno razlikovati neuhranjenost od pothranjenosti. Pothranjenost je unos nedovoljne količine hrane, dok je neuhranjenost definirana kao hranjenje nedovoljno kvalitetnom hranom. Riječi „,ispijenost“, „izmoždenost“ i „marazam" su sinonimi koji se koriste u opisu izgladnjelih, iako je pojam „marazam“ ograničen na opis dojenčadi kao žrtava.

Unutarnji i vanjski čimbenici mogu u istom smislu dovesti do razvijene kliničke slike kaheksije (slika 1). Stoga u kaznenim djelima koja se odnose na zlostavljanje i zanemarivanje i kod kojih se sumnja da je gladovanje koje je uzrokovalo gubitak tjelesne težine rezultat namjerne uskrate hrane, sudski medicinar mora prikupiti što više dokaza izgladnjivanja. Ovo je važno u kasnijem sudskom postupku, s obzirom na to da sama činjenica proteinsko-energijske pothranjenosti i neće biti sporna u onoj mjeri koliko će se raspravljati o postojanju namjerne uskrate hrane. Upravo ta razlika između uzroka i posljedice postat će iznimno bitna jednom kada su podnesene kaznene prijave.

$U$ većini slučajeva, djeca mlađa od 3 godine, te rjeđe starije osobe i/ili bespomoćni ljudi (sve one skupine kod kojih postoji nerazmjer snaga između žrtve i počinitelja) budu žrtve namjerne uskrate hrane. Posebno je kod dojenčadi, uz procjenu sa- 


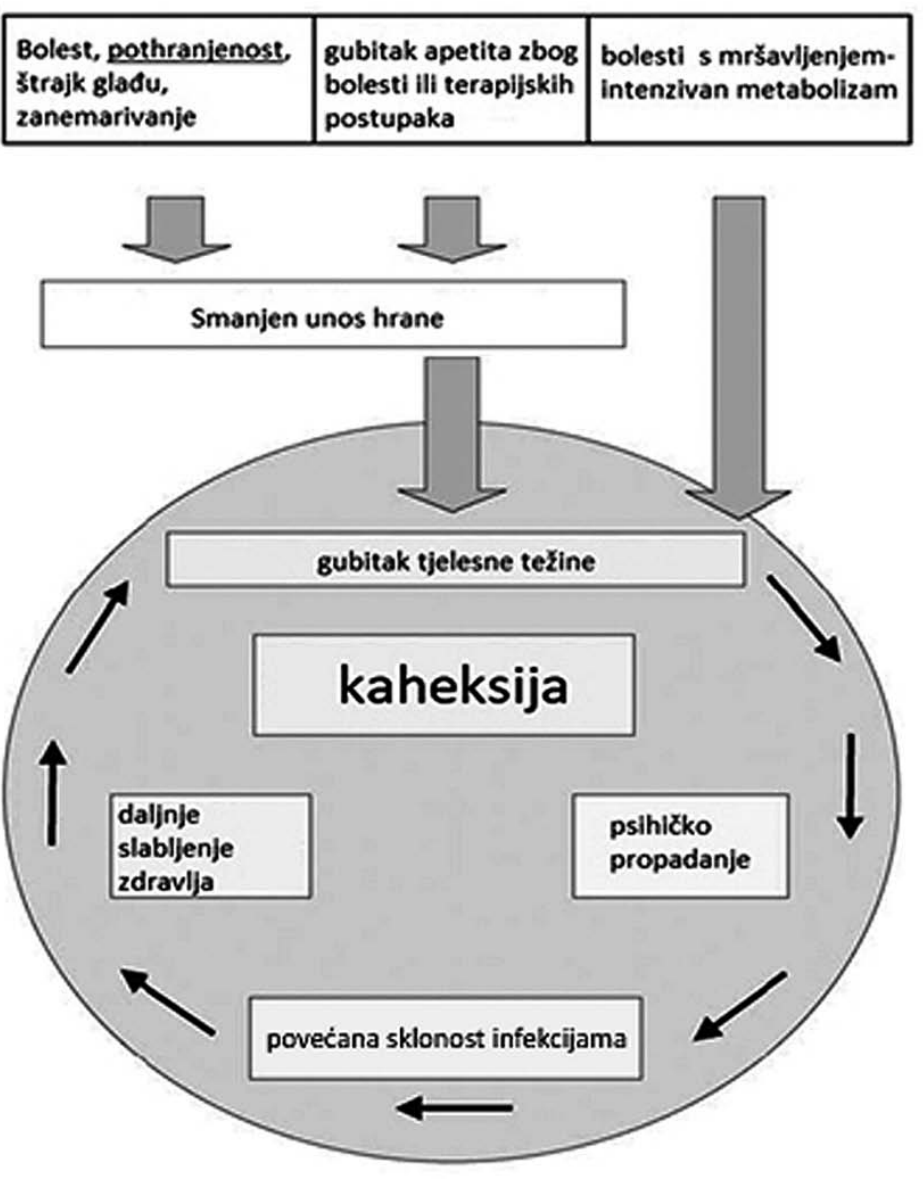

Slika 1. Patogeneza kaheksije. Začarani krug u progresivnim stadijima bolesti, pothranjenosti i zanemarivanja.

mog stvarnog gubitka tjelesne težine, važno dati stručno medicinsko mišljenje u kojoj je mjeri smanjena tjelesna težina mogla biti uzrokovana kroničnim pothranjivanjem. Klasifikacijski sustavi koji se odnose na proteinsku pothranjenost razvijeni su upravo s namjerom da se pojednostavi procjena pothranjenosti u zemljama trećeg svijeta.
KLINIČKI I OBDUKCIJSKI NALAZI KOD GLADOVANJA

Zadovoljenje dnevnih potreba za kalorijama i nadilaženje osnovnih metaboličkih zahtjeva u principu ovisi o tjelesnoj aktivnosti (Tablica 1)2,3. Nedovoljan unos kalorija u odnosu na dnevne potrebe rezultira negativnom energetskom ravnotežom, što dovodi do gubitka tjelesne težine.

O gladovanju kao sudskomedicinskom pitanju u javnosti se intenzivno govori od Drugog svjetskog rata, od kada datiraju prve spoznaje o kliničkoj slici i patofiziologiji izgladnjivanja. Tada uočene spoznaje utemeljene su na iskustvima stečenima promatranjem i izučavanjem žrtava iz nacističkih koncentracijskih logora ${ }^{4-6}$. Više ili manje konstantni simptomi gladi razvijaju se u karakterističnom kronološkom redoslijedu:

1. Gubitak općeg dobrog osjećanja i osjećaj gladi, bolovi u glavi i neodoljiva želja za hranom.

2. Apatija i umor.

3. Gubitak težine, brži prvih mjeseci gladovanja.

4. Pojava kožnih pigmentacija, kaheksija i hipotermija.

5. Ekstremna letargija, mentalna retardacija i gubitak samopoštovanja.

6. Edem.

7. Smanjena otpornost na infekcije općenito i razvoj proljeva i tuberkuloze ili oportunističkih infekcija.

Čak i nakon podužeg gladovanja, odnosno u uznapredovanim fazama gladi, smrt može biti iznenadna i neočekivana ${ }^{7,8-10}$.

Antropometrijski podaci izgladnjelih osoba i podaci o težini organa rutinski se uspoređuju s općom/referentnom populacijom. Ovi podaci predstavljaju osnovu za postavljanje dijagnoze gladovanja. Međutim, uobičajeno uspoređivanje s referentnim vrijednostima ili percentilnim krivuljama nije dovoljno pouzdamo za ocjenjivanje stupnja pothranjenosti.

Tablica 1. Dnevne potrebe za kalorijama kod čovjeka

Način pretvorbe energije

Bazalni metabolizam (tridesetogodišnja osoba koja teži $70 \mathrm{~kg}$, visine $175 \mathrm{~cm}$ )

Bazalni metabolizam + lagana fizička aktivnost

Bazalni metabolizam + težak fizički rad

\section{Potrebe za energijom}

Žene (kcal/dan)

Muškarci (kcal/dan)

1500

1700

1900

3700
2300

4800 


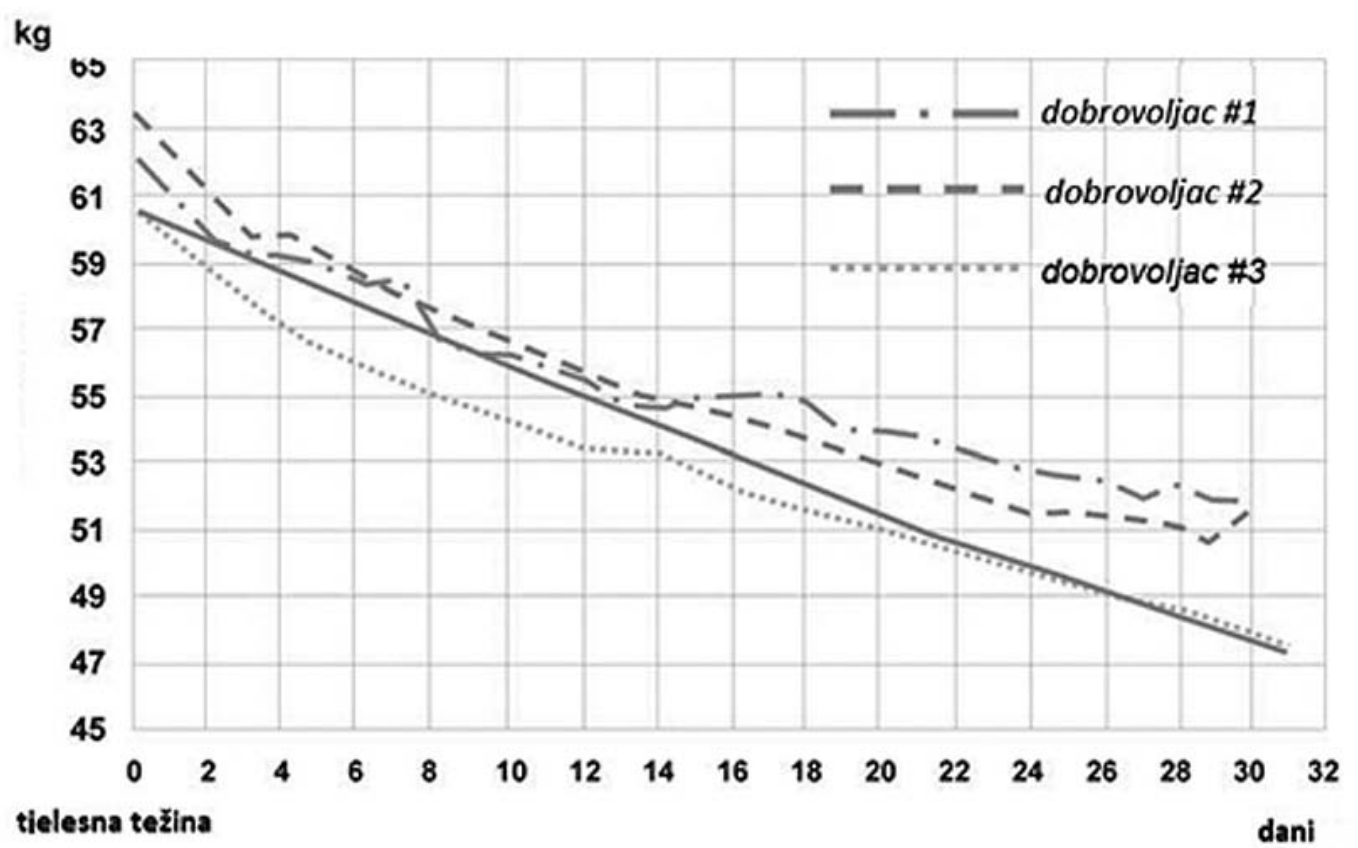

Slika 2. Gubitak tjelesne težine u tri muška dobrovoljca nakon potpune uskrate hrane tijekom 30 dana (ograničeno samo na unos vode). Nakon naglog gubitka tjelesne težine prvih dana, smanjenje tjelesne težine se usporava. Neisprekidana linija predstavlja izračunati prosječni gubitak tjelesne težine.

Tablica 2. Gubitak tjelesne težine (postotak ukupne uobičajene težine tijela) i gubitak težine unutarnjih organa (postotak uobičajene težine unutarnjih organa) kao rezultat gladi u čovjeka.

\begin{tabular}{|l|c|c|c|c|c|c|}
\cline { 2 - 6 } \multicolumn{1}{c|}{} & $\begin{array}{c}\text { Prym } \\
\mathbf{( 1 9 1 9 . )}\end{array}$ & $\begin{array}{c}\text { Krieger } \\
\mathbf{( 1 9 2 1 . )}\end{array}$ & $\begin{array}{c}\text { Giese } \\
\mathbf{( 1 9 4 4 . )}\end{array}$ & $\begin{array}{c}\text { Stein i Feinigstein } \\
\mathbf{( 1 9 4 6 . )}\end{array}$ & $\begin{array}{c}\text { Uehlinger } \\
\mathbf{( 1 9 4 8 . )}\end{array}$ \\
\hline postotak ukupne uobičajene težine tijela & $>27$ & $38-43$ & $>40$ & n. d. & $5-40$ \\
\hline postotak uobičajene težine unutarnjih organa \\
\hline jetra & 11 & 40 & 28 & 46 & 30 \\
\hline srce & 23 & 33 & 24 & 20 & 30 \\
\hline pankreas & n. d. & n. d. & n. d. & n. d. & 10 \\
\hline bubrezi & 6 & 36 & 0 & 25 & 10 \\
\hline slezena & 33 & 46 & 20 & 48 & 0 \\
\hline mozak & n. d. & 4 & n. d. & 7 & 10 \\
\hline hipofiza & 25 & n. d. & 0 & n. d. & n. d. \\
\hline nadbubrežna žlijezda & n. d. & n. d. & 0 & n. d. & n. d. \\
\hline
\end{tabular}

Dominantni nalaz na obdukciji je ekstremna izmoždenost s gubitkom tjelesne težine (mršavost) i težine pojedinih organa (Slika 2, Tablica 2). Gotovo svi organi osim mozga su smanjene težine. Gubitak ukupne težine tijela zbog gubitka potkožnog masnog tkiva i masnog tkiva koje okružuje unutarnje organa u početku je vrlo brz, ali postaje sporiji nakon približno 3 mjeseca ${ }^{2,4,11,12}$. Dolazi i do gubitka tjelesne težine zbog atrofije unutarnjih organa i mišića (Tablica 2). Već i gubitak oko 35 - 50 \% tjelesne težine može uzrokovati smrt.
Dosta je karakterističan i gubitak Bichatova masnog jastučića (Corpus adiposum buccae). Nadalje, atrofija endokrinih i reproduktivnih žlijezdi vrlo su karakteristični znakovi gladovanja. U dojenčadi su potpuna atrofija timusa i smanjenje veličine limfnih čvorova simptomatski za gladovanje ${ }^{13-16}$.

Žučni mjehur obično se nađe proširen, što je rezultat odsutnosti hrane kao prirodnog stimulansa za izlučivanja žuči. Želudac i tanko crijevo obično su prazni, ali prisutnost izuzetno suhe fekalne 
mase u debelom crijevu još je jedan karakterističan nalaz. Čak se i strano tijelo može naći u debelom crijevu, što ukazuje da je gladna osoba prije smrti pokušala jesti sve što je bilo dostupno ${ }^{16,17}$.

Svi ostali nalazi proizlaze iz temeljnog prehrambenog deficita; primjerice, interkurentne infekcije, avitaminoze, promjene na koži i edem. Dehidracija, hipotermija i nekroza ekstremiteta najteže su manifestacije koje pridonose smrti. Većina zanemarene i preminule dojenčadi bila je mlađa od jedne godine. Na obdukciji se mora posvetiti velika pažnja uzimanju tjelesnih mjera koje se moraju uistinu izmjeriti, a ne procijeniti. Trebaju biti pouzdano utvrđene dimenzije: dužina od tjemena do pete, promjer glave, duljina nogu i točna težina kako bi se provela adekvatna usporedba sa standardnim pedijatrijskim percentilnim krivuljama.

Promjer udova mjeren na znakovitim pozicijama (npr. u razini trohantera, zapešća ili gležnjeva) treba mjeriti fleksibilnom trakom. Fotografije treba uzeti sa što većom žarišnom udaljenošću, po mogućnosti u boji, kako bi se razaznavali tonovi i lezije kože, kao i da bi se što jasnije uočio prevladavajući aspekt ispijenog tijela. Riječi „ispijenost“, „izmoždenost“ i „marazam“ su sinonimi koji se koriste i danas, iako je pojam marazam ograničen na opis dojenčadi kao žrtava. Međutim, takozvano „Hipokratovo lice” nije pojam ograničen samo na izmoždenost od zanemarivanja, s obzirom da izmoždenost iz bilo kojeg razloga, poput, primjerice, opstrukcije karcinomom jednjaka, može dovesti do istog izgleda. Koža lica je položena tijesno preko jagodica; obrazi su upali i linije čeljusti su nametljivo vidljive. Oči su duboko potonule zbog gubitka orbitalne masti, iako i dehidracija može pridonijeti takvom izgledu.

$\mathrm{Na}$ trupu se vidno ističu rebra, s konkavnim međurebrenim prostorima i udubinama na mjestu supraklavikularnih jama. Trbuh je klasičnog oblika čamca čiji se vrhovi uzdižu prateći oblik krila crijevnih kostiju. Udovi su gotovo goli kostur, budući da je došlo do posvemašnjeg gubitka masti i mišića. Iz istog razloga se glava može činiti velika u usporedbi sa suženim vratom.

Izgled kože ovisi o dužini postmortalnog vremena, posebno ako je do smrti došlo i zbog uskrate hrane koja je trebala služiti kao izvor određenih vitamina. Koža može biti blijeda, sjajna i gotovo providna, u dojenčadi s praktički plavom nijansom, što je dijelom rezultat gubitka potkožnog masnog tkiva. No, ona isto tako može biti gruba i hrapava, s hiperkeratozama koje se ljušte, što je češće vidljivo u osoba starije životne dobi. Dijelom je to rezultat senilnih promjena. Pigmentacija se nađe ponekad, bilo da je difuzna ili da se radi o jednom točkastom žarištu.

Dehidracija je česta pojava kod žrtava izgladnjivanja, posebno u dojenčadi gdje posebno uvelike pridonosi smrti. Koža dehidriranih je suha i naborana, a kad se uhvati između prstiju, zbog gubitka potkožnog masnog tkiva i tekućine ostaje uštipnuta. I fontanele mogu biti udubljene zbog gubitka volumena likvora.

Infekcije kože su česte; dijelom je to rezultat gubitka imuniteta zbog prehrane, a djelomično zbog zanemarivanja njege i higijene, posebno u dojenčadi. Pritisci koštanih izbočina, primjerice na stražnjici, petama i leđima, mogu se javiti i u djece i u osoba starije životne dobi, koje su nepokretno ležale uslijed slabosti. Nastanku infekcija kod dojenčadi pridonosi i izloženost urinu (dermatitisi), što može progredirati do potpunog nedostatka kože. Rane se mogu vidjeti na svakom mjestu pritiska ili trenja, kao što su koljena, laktovi, ramena i zatiljak. Osim na područjima tlaka, površne infekcije kože mogu se razviti bilo gdje na tijelu, što često cijeli krustom nakon djelomičnog ozdravljenja. Rane na usnama, blefaritisi i konjuktivitisi također se mogu pojaviti. Kosa je suha i lomljiva, a ponekad čak i depigmentirana.

Gubitak masnog tkiva poput ovog opisanog bit će uočljiv i na unutarnjem pregledu, jer osim potkožnog masnog tkiva gube se i unutarnje uskladištene masnoće, primjerice iz omentuma, mezenterija i perirenalnog područja.

Atrofija organa bit će jasnije uočljiva u osoba starije životne dobi, ali u tim slučajevima postoji problem razlikovanja atrofije do koje je došlo zbog prehrambene uskrate i one koja nastaje uobičajeno zbog dobi. Razlika je najčešće samo u stupnju, budući da kronično izgladnjivanje može uzrokovati atrofiju nevjerojatnih razmjera, dok je ona koja se uobičajeno razvija starenjem ipak umjerenija. Puno konkretniji unutarnji znakovi uključivat će prazne šuplje probavne organe, što 
može uključivati probavnu cijev ispunjenu slinom i želučanom sluzi. Bilo kakav fekalni sadržaj u rektumu zasigurno će biti sasušen i formirati fekolite koji mogu i ulcerirati crijevnu sluznicu. Još je izglednije da će fekalna masa formirati fekolite ako je uskratu hrane pratila i dehidracija. U izgladnjele dojenčadi, s druge strane, stolica može biti tekuća i jako smrdljiva, osim kod iznimno izražene dehidracije. Jezik može biti čvrsto obložen, no to je izuzetno nespecifičan nalaz, te nema nikakvog praktičnog značenja.

Patohistološki pregled uglavnom služi isključivanju drugih uzroka smrti i stjecanju informacija o temeljnim prirodnim uzrocima izmoždenosti ili uskrate hrane. Ako su dijagnoze koje su prouzročile smrt neupitno povezane s izgladnjivanjem, treba odrediti stvarni uzrok smrti: prethodne bolesti (npr. malapsorpcija, karcinom) ili uskrata hrane. Tipična slika izmoždenosti i mršavosti te isključenje bilo kojeg drugog uzroka smrti preduvjet su za konačnu dijagnozu smrti kao rezultata gladovanja2,18-21.

Čini se da zarazne bolesti kao neposredni uzrok smrti nisu toliko česte kao što je objavljivano u ranijoj literaturi. Postavlja se, stoga, pitanje: „Koji je neposredni uzrok smrti kod osoba koje su umrle gladujući?" Nedavni prikazi slučajeva o iznenadnoj smrti kod anoreksije ukazuju na to da su ventrikularna tahikardija ili hipoglikemična koma neposredni uzroci iznenadne smrt kod osoba umrlih u gladovanju i anoreksiji. Međutim, oba ova stanja ne mogu se dijagnosticirati postmortalno. Slučajevi iznenadnih smrti teško pothranjenih osoba i onih iznimno mršavih već su opisivani u literaturi. U svojoj knjizi o pothranjenosti koja je objavljena 1947. Wolf-Eisner je pisao o tome da su neishranjeni zatvorenici koncentracijskih logora uglavnom iznenada umirali, npr. tijekom razgovora ${ }^{2}$.

\section{SLUČAJEVI OPISANI U LITERATURI}

Madea i sur. opisuju šest slučajeva izgladnjivane djece koji su za krajnji ishod imali smrt. U trenutku smrti ova su djeca bila između 3 mjeseca i 2,5 godine stara, a među njima su bili i monozigotni blizanci. Potonji je slučaj posebno interesantan ako se izučava postnatalni razvoj (konkretno, prirast težine) kod oba blizanca. Potpuno je identi- čan u svim segmentima, pa čak i u pogledu razvoja teškog marazma. Oba blizanca su pronađena mrtva $u$ istoj sobi, $u$ dobi od 2,5 godine $s$ gotovo identičnim rektalnim temperaturama $i$ vrijednostima kalija u staklovini, što ukazuje na to da su oba umrla približno istovremeno. Toksikološka analiza bila je negativna i uzrok smrti je naveden kao kombinacija gladi i dehidracije. Majka, koja je bila kronični alkoholičar, patila je od teškog alkoholnog oštećenja jetre, i očito je ostavila dojenčad bez hrane i tekućine posljednjih dana života, a svjedoci su posvjedočili da je dojenčad uvijek bila pothranjena ${ }^{2}$.

Neka su od pronađenih tijela u slučajevima koje opisuju Madea i sur. već bila u ranom stadiju truljenja. Svih šest žrtava pronađeno je u iznimno zapuštenim i neurednim stanovima, a prezentirale su se u stanju teške iscrpljenosti. Vanjskim je pregledom kod svih utvrđeno gotovo potpuno odsustvo masnih jastučića u obrazima i trbušnom zidu. Na obdukciji gotovo da ni nije bilo masnog tkiva među listovima mezenterija². U svim ovim slučajevima uočen je „suhi” oblik teške iscrpljenosti/ izmoždenosti s prisutnim znakovima dehidracije $^{17}$.

U svojem opisu pet slučajeva ubojstva djece izgladnjivanjem Adelson daje i pojedinosti o visini i težini tijela, tako da je moguća primjena Waterlowljeve klasifikacije22. Kod svih Adelsonovih slučajeva stvarna težina u usporedbi s očekivanom tjelesnom težinom ukazuje na pothranjenost koja teško ugrožava život. Naime, sva dojenčad bila je znatno ispod kritičnih vrijednosti, odnosno postotak idealne težine za visinu bio je ispod $70 \%$, što ukazuje na tešku pothranjenost ${ }^{23,24}$.

Razumljivo, u literaturi ne postoje empirijski provjerene granične vrijednosti tjelesne težine kod kojih nastupa smrt zbog izgladnjivanja. Postoje, doduše, s jedne strane neki objavljeni prikazi slučajeva izgladnjivanja kod kojih je korištena Waterlowljeva klasifikacija, a s druge strane, stvarna težina u vrijeme smrti ovisi i o čimbenicima poput dehidracije, infekcije i ostalog. Upravo navedeni slučajevi potvrđuju valjanost ocjenjivanja proteinsko-energijske uhranjenosti prema Waterlowljevoj klasifikaciji.

Kod starije djece pothranjenost je, što je i razumljivo, trajala duže; budući da je težina, barem 
kroz neko vrijeme, ostala konstantna (čitavo vrijeme je riječ o tjelesnoj težini kao postotku koeficijenta idealne tjelesne težine i izmjerene visine), što je posljedica zaostajanja u rastu).

Iz istog ovog razloga kod mlađe dojenčadi pothranjenost brže uzrokuje smrt, čemu u prilog govore i tri slučaja koje prikazuju Wehner i sur. Radi se o tri muška djeteta iz udomiteljske obitelji. Jedan od dječaka (slučaj 1) umro je od gladi u dobi od 5 godina. Nakon njegove smrti, dvojica živih dječaka (slučaj 2 i 3; u dobi 6,5 i 8,5 godina) podvrgavana su liječničkim pregledima te je kod oba primijećeno usporavanje rasta u visinu i teška akutna neishranjenost (usporavanje rasta u visinu od $80 \%$ do $87 \%$, te neishranjenost $60 \%$ do $65 \%$ težine u odnosu na stvarnu visinu). Dakle, shodno navedenome, kod petogodišnjeg dječaka koji je umro (slučaj 1), zabilježen je najveći gubitak tjelesne težine u odnosu na stvarnu visinu i očekivanu težinu.

POTHRANJENOST I DEHIDRACIJA KAO POKAZATELJI ZANEMARIVANJA OSOBA STARIJE ŽIVOTNE DOBI

Pothranjenost i njen krajnji oblik, kaheksija, proizlaze iz neodgovarajuće potrošnje bitnih hranjivih tvari te mogu biti smrtonosni. Među osobama starije životne dobi najčešći tip pothranjenosti je proteinsko-energijska pothranjenost. Pothranjenost sama po sebi može biti posljedica zanemarivanja od strane skrbnika. Isto tako, mnogo je faktora vezanih za osobine same žrtve, odnosno njenu dob, koji mogu dovesti do gubitka apetita i smanjenja težine, u rasponu od nedostataka nekoliko ili svih zuba ili proteze koja loše pristaje, pa do demencije. Osobe starije životne dobi nerijetko uzimaju raznoliku medikamentoznu terapiju, između ostaloga i psihofarmake, a najčešće propisivani psihotropni lijekovi potiskuju želju za jelom. Neke neurološke bolesti mogu uzrokovati poteškoće sa žvakanjem i gutanjem, što skrbnik ili ignorira i nasilno hrani ili zanemari osobu starije dobi. U oba slučaja, uslijed epizode gušenja sa smrtnim ishodom (varijacija iznenadnog kolapsa za vrijeme jela koji nerijetko završi smrću) ili aspiracije može nastati upala pluća ${ }^{25}$.

Quinn i Tomita definiraju značajan gubitak težine kako slijedi: $5 \%$ (ispod početne vrijednosti) u 1 mjesec, $7 \%$ u 3 mjeseca i $10 \%$ u 10 mjeseci $^{26}$.
Gubitak više od $40 \%$ početne vrijednosti tjelesne težine može biti smrtonosan. Klinički, anemija nastala od neishranjenosti može biti znak zanemarivanja. Mjerenje serumskog albumina je specifičnije za ukazivanje na pothranjenost od samog gubitka težine ${ }^{27}$. Pothranjenost obično pokreće začarani krug, povećava se podložnost infekciji i stvaranje kožnih čireva, što zahtijeva više kalorija i proteina.

Na obdukciji, uz mjerenje tjelesne težine i vaganje utrobnih organa (Tablica 2), forenzičar treba dokumentirati sadržaj cijelog gastrointestinalnog trakta i mikroskopski ispitati nadbubrežne žlijezde tražeći pokazatelje koji ukazuju na stresne promjene u kori. U studiji Shieldsa i sur. ${ }^{28}$ čak $36,4 \%$ pacijenata uvrštenih u studiju, prema kriteriju indeksa tjelesne mase (BMI), svrstani su u kategoriju anoreksičnih osoba (BMI < $17.5 \mathrm{~kg} / \mathrm{m}^{2}$ ). To je ipak nešto manje od udjela pacijenata uvrštenih u studiju kod kojih je evidentirana premala težina s obzirom na visinu (40,9\%), odnosno čiji je BMI $=17,5-20 \mathrm{~kg} / \mathrm{m}^{2}$.

Često se i kod osoba starije životne dobi javlja dehidracija, odnosno uz pothranjenost prisutna je i nedovoljna količina ukupne tjelesne tekućine. Osobe starije životne dobi sklone su dehidraciji zbog starosnih promjena u održavanju homeostaze tekućine. Bolesti poput infekcija ili proljeva, kao i lijekovi poput diuretika, mogu biti odgovorni za takvo stanje. S druge strane, dehidracija može biti posljedica skrbničkog zanemarivanja u slučajevima kad ne postoji praćenje unosa tekućine. Klinički znakovi dehidracije mogu biti teško rješivi zbog preklapanja $s$ drugim uvjetima kod osoba starije životne dobi ${ }^{9,30}$.

KLASIFIKACIJA PROTEINSKO-ENERGIJSKE POTHRANJENOSTI

U brojnim slučajevima izgladnjivanja sa ili bez smrtnog ishoda, viđenih na kraju Drugog svjetskog rata u nacističkim koncentracijskim logorima, zapažene su dvije glavne vrste žrtava, tzv. „suhi” i „mokri” tip.

U prvom je dominirala izmoždenost, tjelesna težina smanjena je do pola normalne, a edem je prisutan samo na nogama. Ovakvi unesrećenici pokazali su značajnu hipotenziju, slab puls i cijanozu. Druga skupina imala je primjetan edem lica, 
trupa i udova, s ascitesom i pleuralnim izljevom. Hipoproteinemijski edem uzrokovan je preusmjeravanjem proteina za sintezu energije, budući da su ugljikohidrati i masnoća slabo prisutni u prehrani. U nekih je žrtava na kostur otpadalo $50 \%$ tjelesne težine, umjesto uobičajenih $15 \%$.

Kao što smo već napomenuli, tijekom posljednjih desetljeća razvijeno je nekoliko klasifikacijskih sustava za procjenu proteinsko-energijske pothranjenosti. Ove klasifikacije su nadmoćnije i primjenjivije $u$ odnosu na percentilne krivulje, a sudski medicinari ih radije rabe jer antropometrijski podaci koje koriste omogućuju i procjenu stupnja pothranjenosti. Ti se stupnjevi proteinsko-energijske pothranjenosti uspješno primjenjuju na pojedincima u zemljama trećeg svijeta, ali se mogu koristiti i za klasifikaciju dojenačke i dječje pothranjenosti u slučajevima izgladnjivanja koje je rezultat namjernog uskraćivanje hrane ${ }^{2,17}$. Bitno je sagledati dimenzije cijelog tijela (i težine pojedinih organa), tako da se ukupne dimenzije tijela i pojedine proporcije mogu uspoređivati s referentnim vrijednostima ${ }^{31,32}$. Tjelesna težina pa ni pothranjenost ne bi se trebale uspoređivati samo s očekivanom težinom za odgovarajuću dobnu skupinu, već bi se uvijek trebali koristiti adekvatni klasifikacijski sustavi, tim više što pothranjenost nije uvijek akutna, već može biti i kronična ${ }^{2,33}$. Klasifikacijski sustavi, poput Waterlowljeve klasifikacije ${ }^{34}$, mogu biti osobito korisni u razlikovanju akutne od kronične neishranjenosti, a svi sustavi koji su trenutno u upotrebi uzimaju u obzir očekivanu težinu za odgovarajuću dobnu skupinu kao standard.

Ipak, koristeći klasifikacijske sustave koji su trenutno u upotrebi, dojenčad će uvijek biti lagane, pa razlikovati kroničnu od akutne pothranjenosti kod sasvim male dojenčadi nije moguće. Osim toga, dojenčad koja je visoka za svoju dob i ima smanjenu tjelesnu masu bit će klasificirana kao normalna, stoga u takve dojenčadi stanje kronične pothranjenosti ne može biti prepoznato ${ }^{17}$. Bilo kako bilo, ovi su klasifikacijski sustavi kvalitetniji i precizniji u odnosu na orijentaciju prema percentilnim krivuljama, tim više što Waterlowljeva klasifikacija proteinsko-energijske pothranjenosti, primjerice, ne uzima u obzir samo težinu, već i visinu, te očekivanu težinu za stvarnu visinu ${ }^{35-37}$. Korištenjem ovog klasifikacijskog sustava postaje očito da je dojenčad laka za svoju dob (gubitak tjelesne težine od 50 \% standardne vrijednosti za istu dobnu skupinu) manja rastom, što je odraz kronične pothranjenosti.

TRAJANJE GLADOVANJA, TJELESNO STANJE PRIJE SMRTI I NEPOSREDNI UZROK SMRTI

Vjerojatno je da će potpuna uskrata hrane uzrokovati smrt za oko 50 - 60 dana, naime, organizam tolerira glad dok god postoji odgovarajuća opskrba vodom, što ovisi o vremenu i temperaturi okoline, kao i o tjelesnoj kondiciji žrtve i njenoj tjelesnoj masnoći. Potpuna uskrata vode dovodi do letalnog ishoda za oko 10 dana, ili kraće kod viših temperatura okoline ${ }^{2}$. Nerijetko se u kazneno-pravnim postupcima od vještaka/ specijalista sudske medicine traži da procijeni ukupno vremensko trajanje uskrate hrane i/ili tekućine. Primjer kako izračunati ukupni kalorijski deficit $s$ ciljem određivanja stupnja i trajanja deprivacije objavili su Meade i Brissie $1985^{38}$. Nažalost, čini se da je primjer izračuna poput ovog upotrebljiv samo u slučajevima akutnog izgladnjivanja, kod kojeg je primijećena potpuna uskrata hrane, no ne i u slučaju kronične pothranjenosti. Ipak, informativni podaci koje pružaju takvi primjeri izračuna mogu dati savjete informativne prirode o minimalnom vremenskom intervalu u kojem je postojalo apsolutno uskraćivanje hrane.

Podaci koji su do sada objavljeni, a odnose se na trajanje razdoblja uskraćivanja hrane do smrti, u prvom redu su podaci koji se tiču odraslih osoba, slučajeva akutnog uskraćivanja hrane i tekućine koji završe smrtno, te dojenčadi s urođenim abnormalnostima gornjeg dijela gastrointestinalnog trakta. Prema prikazanim slučajevima desetorice mladih, prethodno zdravih štrajkača glađu (srednje dobi 25,6 \pm 0,7 godina), razdoblje preživljavanja varira između 53 i 73 dana (prosječno $61 \pm 2,5$ dana $)^{11}$. Ti podaci, međutim, ne mogu biti upotrebljivi u slučajevima kroničnog gladovanja, posebno u slučajevima prerano rođene dojenčadi.

Dokazi o trajanju pothranjenosti traže se prvenstveno u medicinskoj dokumentaciji žrtava (tjelesna masa, visina). Vještaku specijalistu sudske medicine može se postaviti upit koliko vremena prije smrti je pothranjenost žrtve bilo moguće uočiti. U takvim slučajevima preporučljivo je 
odrediti približni vremenski interval prije smrti, pri čemu kao polazište valja uzeti podatak da potpuno uskraćivanje hrane rezultira gubitkom tjelesne težine tempom od oko 0,7 do $1 \%$ ukupne tjelesne težine dnevno. Koristeći Waterlowljevu klasifikaciju, tjelesna masa uspoređena s idealnom težinom za realnu visinu daje nam pravi dojam o težini pothranjenosti. Kada uskrata hrane nije bila potpuna, može se pretpostaviti da je početna stvarna tjelesna težina bila niža, te se „trošila" kroz pretpostavljeno vrijeme kroničnog

Više ili manje konstantni simptomi gladi razvijaju se na sljedeći karakterističan način: gubitak općeg dobrog osjećanja i osjećaj gladi, bolovi u glavi i neodoljiva želja za hranom; apatija i umor; gubitak težine; pojava kožnih pigmentacija, kaheksija i hipotermija; psihički simptomi; edem; smanjena otpornost na infekcije općenito i razvoj proljeva.

gladovanja. Kao što smo nekoliko puta u tekstu i spomenuli, izgladnjivanje do smrti može biti praćeno dehidracijom, što onda može biti neposredni uzrok smrti. Dijagnoza dehidracije temelji se na klasičnim nalazima obdukcije, kao što je gubitak tjelesne težine, „upale“ oči, slab turgor i smanjen tonus kože, te suhe površine unutarnjih organa na rezanim plohama. Biokemijske pretrage - iako ih u nekim publikacijama preporučuju, u ovom trenutku nisu dovoljno pouzdane pri postmortalnom utvrđivanju dehidracije ${ }^{30,39}$. Posebno valja istaknuti kako rezultati pretraga staklovine trenutno nisu dovoljno pouzdani za izvođenje zaključaka o antemortalnim poremećaja metabolizma ili elektrolita ${ }^{2,40}$. To se može pripisati činjenici da dijagnosticiranje poremećaja metabolizma ili elektrolita na temelju analize staklovine umrle osobe obuhvaća i ispitivanja slučajnih uzoraka. Kod slučajno uzetih uzoraka postoje nelogična odstupanja koncentracije analiziranih tvari, što onda govori o iznimno otežanom razlikovanju sigurno normalnih od zasigurno nenormalnih vrijednosti. Sve ove uvjete potrebno je najprije zadovoljiti, odnosno eliminirati kako bi se postavili ispravni znanstveni temelji za primjenu analize staklovine $u$ prosuđivanju relevantnosti odstupanja vrijednosti koncentracija analiziranih tvari u trenutku smrti.
Istraživanja prikazana u literaturi koja dovode u vezu visoku ili nisku vrijednost analiziranih tvari u staklovini mahom ne navode vrijednosti tih istih tvari u serumu ${ }^{2,40,41}$. Osim toga, u literaturi u potpunosti nedostaje prikazanih istraživanja materijala izuzetog tijekom obdukcija, gdje je dijagnoza dehidracije bila postavljena i na temelju nalaza obdukcije, te je vrijednost analiziranih tvari u staklovini umrle osobe uspoređena sa zaživotnim serumskim vrijednostima.

\section{ZAKLJUČAK}

Do smrti kao posljedice izgladnjivanja u razvijenom svijetu najčešće dolazi zbog zanemarivanja socijalno najosjetljivijih kategorija u svim onim situacijama kod kojih je briga o prehrani i osnovnim životnim potrebama prepuštena drugoj osobi. Najčešće se ovdje radi o dojenčadi i djeci do 3. godine života, ali i o starijim osobama koje zbog svog stanja više nisu u stanju brinuti o sebi, te postoji izvjestan nerazmjer u odnosima snaga između žrtve i izglednog počinitelja.

U svim slučajevima kad se oko načina smrti spori pred sudom, a evidentirano je stanje niske težine /neuhranjenosti žrtve, bilo da je u pozadini uskrata ili ravnodušnost pri uzimanju hrane, može se špekulirati kako je neuhranjenost uzrokovana prirodnom bolešću, a ne nasilnim putem. Budući da takva tvrdnja može katkad biti i istina, nužno je poduzeti temeljit liječnički pregled, koristeći sve raspoložive anatomske, histološke i biokemijske infrastrukture.

Ponekad je sa zanemarivanjem povezano i fizičko zlostavljanje, stoga je fotografiranje mrtvog tijela ili radiografija prije obdukcije iznimno bitna radnja - u stvari, cijeli postupak mora biti proveden kao da se radi o pretučenom djetetu. I kod odraslih i kod djece uzročno-posljedični niz je velik izazov za patologa ili specijalista sudske medicine, pogotovo ako se utvrdi postojanje još nekakvog patološkog stanja. Primjerice, u kakvoj su vezi plućna tuberkuloza i tjelesna izmoždenost, odnosno nutritivni deficit? Ali u tom kontekstu moraju biti procijenjeni i važnost, odnosno utjecaj bolesti poput dijabetesa, Addisonove bolest, kroničnih infekcija i neoplazmi. Posebno je važno kod djece razmišljati i o mogućem utjecaju obiteljskih bolesti metabolizma. 
Izjava o sukobu interesa: Autori izjavljuju da ne postoji sukob interesa.

\section{LITERATURA}

1. Saukko P, Knight B. Knight's forensic pathology fourth edition. CRC press, 2015.

2. Madea B. Death as a result of starvation. Forensic pathology reviews. Springer, 2005; 3-23.

3. Beaton GH. Nutritional needs during the first year of life. Some concepts and perspectives. Pediatric Clinics of North America 1985;32:275-88.

4. Giese W,Hörstebrock R. Allgemeine Pathologie des exogenen quantitativen Nahrungsmangels. Ernährung. Springer, 1962; 446-591.

5. Adelsberger L. Medical observations in Auschwitz concentration camp. Lancet 1946;250:317-9.

6. Simpson K. Exposure to cold-starvation and neglect. Modern Trends in Forensic Medicine Butterworth, London 1953;116-32.

7. Smith J. Hypoglycaemic coma associated with anorexia nervosa. Aust N Z J Psychiatry1988;22:448-53.

8. Neumarker KJ. Mortality and sudden death in anorexia nervosa. Int J Eat Disord 1997;21:205-12.

9. Casiero D, Frishman WH. Cardiovascular complications of eating disorders. Cardiol Rev 2006;14:227-31.

10. Sachs KV, Harnke B, Mehler PS, Krantz MJ. Cardiovascular complications of anorexia nervosa: A systematic review. Int J Eat Disord 2016;49:238-48.

11. Leiter LA, Marliss EB. Survival during fasting may depend on fat as well as protein stores. JAMA 1982;248:2306-7.

12. Missliwetz J, Mortinger H. Tod durch Hypoglykaemie nach Hungerzustand Pathophysiologie versus Morphologie. Beitrage zur gerichtlichen medizin 1992;50:319-

13. Gee D. Starvation and neglect. Taylor's Principles and Practice of Medical Jurisprudence Churchill Livingstone, Edinburgh, London, Melbourne, New York 1984;276-9.

14. Ellerstein NS, Ostrov BE. Growth patterns in children hospitalized because of caloric-deprivation failure to thrive. Am J Dis Child 1985;139:164-6.

15. Tanegashima A, Yamamoto H, Yada I, Fukunaga T. Estimation of stress in child neglect from thymic involution. Forensic Sci Int 1999;101:55-63.

16. Nishio H, Matusi K, Tsuji H, Tamura A, Suzuki K. Immunohistochemical study of tyrosine phosphorylation signalling in the involuted thymus. Forensic Sci Int 2000; 110:189-98.

17. Madea B, Michalk D, Lignitz E. Verhungern infolge Kindesvernachlaessigung. Kasuistik und gutachterliche Aspekte (Mit 8 Tabellen). Arch Kriminol 1994;194:29-.

18. Campbell J. The morbid anatomy of infantile malnutrition in Cape Town. Arch Dis Child1956;31:310.

19. Hughes EA, Stevens L, Wilkinson A. Some aspects of starvation in the newborn baby. Arch Dis Child 1964;39:598.

20. Listernick R, Christoffel K, Pace J, Chiaramonte J. Severe primary malnutrition in US children. Am J Dis Child 1985;139:1157-60.
21. Madea B, Henßge C, Berghaus G. Fahrlässige Tötung eines Säuglings durch Fehlernährung. Arch Kriminol 1992;189:33-8.

22. Adelson L. Homicide by starvation. JAMA 1963;186:104.

23. Wehner F, Schieffer MC, Wehner H-D. Percentile charts to determine the duration of child abuse by chronic malnutrition. Forensic Sci Int 1999;102:173-80.

24. Fieguth $A$, Günther $D$, Kleemann WJ, Tröger $H$. Lethal child neglect. Forensic Sci Int 2002;130:8-12.

25. Hunsaker DM, Hunsaker JC, 3rd. Therapy-related cafe coronary deaths: two case reports of rare asphyxial deaths in patients under supervised care. Am J Forensic Med Pathol 2002;23:149-54.

26. Quinn MJ, Tomita SK. Elder abuse and neglect: Causes, diagnosis, and interventional strategies. Springer Publishing Company, 1997.

27. Hunsaker DM, Hunsaker JC. Elder Abuse. Forensic Pathology Reviews. Springer, 2006; 25-62.

28. Shields LB, Hunsaker DM, Hunsaker JC. Abuse and neglect: a ten-year review of mortality and morbidity in our elders in a large metropolitan area. Journal of Forensic Science 2003;49:1-6.

29. DiMaio VJ, DiMaio D. Forensic pathology. CRC press, 2001.

30. Madea B, Musshoff F. Postmortem biochemistry. Forensic Sci Int 2007;165:165-71.

31. Kliegman RM, Behrman RE, Jenson HB, Stanton BM. Nelson textbook of pediatrics e-book. Elsevier Health Sciences, 2007.

32. Bremer H. Protein-Energie-Malnutrition der Entwicklungsländer. Lehrbuch der Kinderheilkunde, 6th ed Thieme Verlag, Stuttgart, New York 1991;247-51.

33. Madea B, Ortmann J, Doberentz E. Forensic aspects of starvation. Forensic science, medicine, and pathology 2016;12:276-98.

34. Gomez F, Galván RR, Cravioto J, Frenk S. Malnutrition in infancy and childhood, with special reference to kwashiorkor. Advances in pediatrics 1955;7:131.

35. Waterlow J. Classification and definition of protein-calorie malnutrition. British medical journal 1972;3:566.

36. Waterlow $\mathrm{J}$. Note on the assessment and classification of protein-energy malnutrition in children. The Lancet 1973;302:87-9.

37. Waterlow JC, Buzina R, Keller W, Lane J, Nichaman M, Tanner J. The presentation and use of height and weight data for comparing the nutritional status of groups of children under the age of 10 years. Bulletin of the World Health Organization 1977;55:489.

38. Meade J, Brissie RM. Infanticide by starvation: calculation of caloric deficit to determine degree of deprivation. Journal of Forensic Science 1985;30:1263-8.

39. Belsey S, Flanagan R. Postmortem biochemistry: current applications. Journal of forensic and legal medicine 2016;41:49-57.

40. Madea B. Postmortale Diagnostik von Störungen des Wasser-und Elektrolythaushaltes. Rechtsmedizin 1996;6:141-6.

41. Madea B. "Normal" Values in Vitreous Humor-Reflections and Refutations. Acta Medicinæ Legalis Vol XLIV 1994. Springer, 1995; 421-4. 